\title{
NOVAC ISTOČNOGOTSKOG KRALJA TEODORIKA IZ LUKARA U PROMINI ${ }^{1}$ \\ A COIN OF THE OSTROGOTHIC KING THEODORIC, DISCOVERED IN LUKAR, PROMINA ${ }^{1}$
}

Tomislav Šeparović

Muzej hrvatskih arheoloških spomenika

Stjepana Gunjače 3

HR - 21000 Split

tomiseparovic@gmail.com
Tomislav Šeparović

The Museum of Croatian Archaeological Monuments

Stjepana Gunjače 3

HR - 21000 Split

tomiseparovic@gmail.com

UDK / UDC: 904:737.1(497.5-37 Promina)"653"

Prethodno priopćenje / Preliminary communication

https://doi.org/10.52064/vamz.54.1.3

Tema je rada zlatni solid istočnogotskoga kralja Teodorika iskovan u ime bizantskog cara Anastazija. Pronađen je na području naselja Lukar, u današnjoj općini Promina, petnaestak kilometara sjeverozapadno od Drniša. Uz kratke crtice o arheološkoj topografiji Lukara, donose se opći podaci o nalazima istočnogotskog novca, posebice u južnoj Hrvatskoj, a Teodorikov solid stavlja se u širi kulturno-povijesni kontekst.

Ključne riječi:

Istočni Goti, Teodorik, Anastazije, Bizant, Lukar, Promina, istočnogotski novac, bizantski novac

Numizmatičku zbirku Muzeja hrvatskih arheoloških spomenika sačinjava vrijedna građa koja predstavlja važan izvor za proučavanje povijesti prostora istočne jadranske obale. Pritom je od posebne važnosti skupina bizantskog i istočnogotskog nov ca jer svjedoči o najintrigantnijem razdoblju hrvatske povijesti od vremena kasne antike do kraja ranoga srednjeg vijeka. U toj je skupini novca i zlatni solid istočnogotskoga kralja Teodorika, pronađen na području naselja Lukar u Promini sjeverozapadno od Drniša. Novac je kovan u kovnici grada Rima u ime bizantskog cara Anastazija. Razmišljajući koju temu odabrati za sljedeći broj „Vjesnika“ Arheološkog muzeja u Zagrebu, posvećenog kolegi Željku Demi, odlučio sam obraditi upravo taj primjerak, i to ne
The subject of this paper is a gold solidus of the Ostrogothic king Theodoric, which was minted in the name of the Byzantine emperor Anastasius. It was discovered in the area of the settlement of Lukar, which is located in the present-day municipality of Promina and about fifteen kilometres northwest of the town of Drniš. In addition to a brief outline of the archaeological topography of Lukar, this paper also provides general information on the findings of Ostrogothic coins, particularly in southern Croatia, while the solidus of Theodoric itself is placed in a broader cultural and historical context.

Key words:

Ostrogoths, Theodoric, Anastasius, Byzantium, Lukar, Promina, Ostrogothic coins, Byzantine coins

The numismatic collection of the Museum of Croatian Archaeo logical Monuments, in Split, consists of valuable material that is an important source for studying the history of the eastern Adriatic coast. Particularly important is the collection of Byzantine and Ostrogothic coins, because it testifies to the most intriguing period of Croatian history, from the time of Late Antiquity to the end of the Early Middle Ages. Also belonging to this group of coins is the gold solidus of Theodoric, king of the Ostrogoths, which was found in the area of Lukar, a settlement in Promina, northwest of Drniš, and minted in the mint of the city of Rome in the name of Byzantine emperor Anastasius. While thinking about which topic to choose for the next issue of the Journal of 


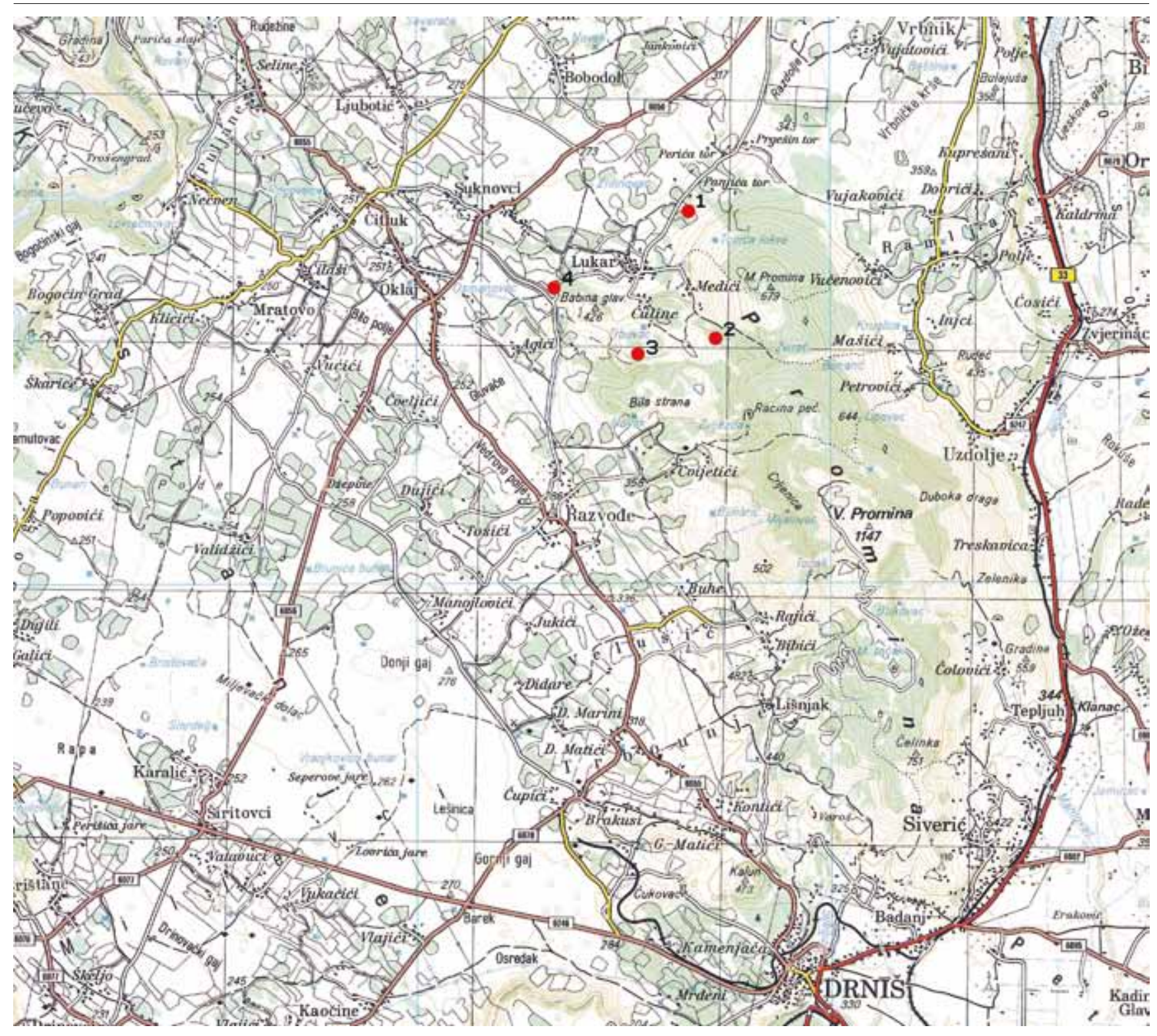

KARTA 1. Zemljopisna karta s označenim nalazištima: 1 - Kosaluša; 2 - Gradina kod Čulina; 3 - Šušelj; 4 - Gospa Čatrnjska (Veliki atlas Hrvatske, 2002.).
MAP 1. Geographical map with marked sites: 1 - Kosaluša; 2 - Gradina kod Čulina; 3 - Šušelj; 4 - Gospa Čatrnjska (Veliki atlas Hrvatske, 2002). slučajno, budući da je upravo kolega Demo velik dio svoje znanstvene karijere posvetio proučavanju istočnogotskog novca i objavio više radova na tu temu, uključujući sjajnu monografiju o istočnogotskom novcu iz zbirki u Hrvatskoj, Sloveniji i Bosni i Hercegovini. $^{2}$

Lukar je naselje u današnjoj općini Promina bogatoj kulturnopovijesnom i arheološkom baštinom. Riječ je o prostoru smještenom između rijeke Krke na zapadu i sjeveru, planine Promine na istoku te Miljevaca na jugu (karta 1). Lukar je u više navrata obilazio Fra Lujo Marun, ostavivši o tome zapise u svojim Starinarskim dnevnicima. ${ }^{3} \mathrm{Na}$ širem području naselja postoje dvije the Archaeological Museum in Zagreb, which is dedicated to my colleague Željko Demo, I decided on this specimen, and this not by chance. For my colleague Demo devoted a good part of his scientific career to studying Ostrogothic coins and has published several papers on the subject, including a brilliant monograph on Ostrogothic coins from collections in Croatia, Slovenia and Bosnia and Herzegovina. ${ }^{2}$

Lukar is a settlement in the present-day municipality of Promina, which is rich in cultural, historical and archaeological heritage. It is an area located between the River Krka to the west and north, the mountain of Promina to the east, and Miljevci to the south 
gradine, obje u blizini zaseoka Čuline. Opisao ih je i nacrtao još u prošlom stoljeću arheolog W. Buttler. ${ }^{4}$ Površinom veća, gradina Šušelj nalazi se južno od spomenutog zaseoka. Za nju se mislilo da u antici nije bila korištena, ali nalaz rimskog brončanoga okova jarma iz 1 . stoljeća to je opovrgnuo. ${ }^{5} \mathrm{Na}$ Šušelju je bilo stećaka, ${ }^{6}$ a u doba osmanskih osvajanja tu je podignuta utvrda koja je bila vidljiva još početkom 20. stoljeća. ${ }^{7}$ Do danas od nje nije ostalo ništa sačuvano jer ju je lokalno stanovništvo razgradilo koristeći kamen kao građevinski materijal. Druga gradina, smještena jugoistočno od zaseoka Čuline, egzistirala je i u prapovijesnom i rimskom razdoblju. ${ }^{8}$ Između nje i Čulina je položaj toponima Mastirine, što ukazuje na moguć arheološki lokalitet. Sjeverno od Gradine vodi put korišten još od prapovijesti za prijelaz preko Promine. U rimskom je razdoblju to bila najkraća komunikacija između vojnog logora u Burnumu s područjem legionarskog posjeda tzv. prata legionis u Kosovu polju, južno od Knina. ${ }^{9}$ Uz spomenuti okov jarma sa Šušelja, rimski arheološki ostaci u Lukaru zastupljeni su nalazima natpisa i opeke. ${ }^{10}$ Brončani novac pronađen na zemljanom putu, koji sa sjeverozapadne strane Šušelja vodi prema selu, po opisu bi također trebao biti iz rimskog razdoblja. ${ }^{11}$ Kasnoantička građevina otkrivena je pokraj Crkve Gospe Čatrnjske koja dominira na prilazu selu s jugozapadne strane. ${ }^{12}$ Moguće da je riječ o rimskom gospodarskom objektu preinačenom i korištenom u starokršćanskom razdoblju. Nalazi više ulomaka ranosrednjovjekovne skulpture ukazuju na to da je u blizini postojala predromanička crkva. ${ }^{13}$ Iz grobova otkrivenih uz župnu crkvu potječu naušnica i željezna ostruga pa se, s obzirom na nalaze skulpture i stećaka, može pretpostaviti da je riječ o groblju koje se razvilo uz crkvu i trajalo do kasnoga srednjeg vijeka. ${ }^{14} \mathrm{O}$ značaju Lukara u doba ranosrednjovjekovne Hrvatske kneževine posebice svjedoče zlatnici bizantskog cara Teofila od kojih je jedan pronađen na Gradini, dok je drugi s nepoznatog poIožaja. ${ }^{15}$ U siječnju i veljači 2021. godine s kolegicom Majom Petrinec obilazio sam Lukar u pratnji mještanina g. Josipa Čuline, koji nam je dao više zanimljivih informacija o ovome kraju. ${ }^{16} \mathrm{Nas}$ je osobito zanimao položaj Kosaluša jer je tu godine 1910., orući njivu, Luka Sarić iz Lukara pronašao zlatni Teodorikov novac. ${ }^{17}$ Položaj Kosaluša nalazi se sjeverno od sela u podnožju male Promine. Riječ je o više zemljišta koja, zajedno s položajem zvanim Banica,
(Map 1). The Franciscan monk Lujo Marun visited Lukar on several occasions and left records about it in his Archaeological Journals. ${ }^{3}$ There are two hill-forts in the wider area of Lukar, and both are located near the hamlet of Culine. They were described and illustrated by archaeologist W. Buttler in the last century. ${ }^{4}$ Šušelj, the larger hill-fort, is located south of the hamlet. It was thought that it had not been used in antiquity, but the finding of a Roman bronze brace belonging to a yoke from the first century refuted this assumption. ${ }^{5}$ There were tombstones on Šušelj, ${ }^{6}$ and also a fortress that was built during the Ottoman conquests and still visible at the beginning of the $20^{\text {th }}$ century. ${ }^{7}$ However, there are no remains of this fortress today, because the locals dismantled it, using its stone as building material. The second hillfort, located southeast of the hamlet of Čuline, existed in prehistoric and Roman times. ${ }^{8}$ Between this hill-fort and Čuline is the location of Mastirine, a toponym which indicates a possible archaeological site. North of Gradina is a road that has been used since prehistoric times to cross over Promina. In Roman times, it was the shortest connection between the military camp in Burnum with the fields of the legion, the so-called prata legionis in the Kosovo plain, south of Knin. ${ }^{9}$ In addition to the above-mentioned brace of a yoke from Šušelj, archaeological remains from Roman times in Lukar are also represented by finds of inscriptions and bricks. ${ }^{10}$ The bronze coin that was discovered on the earth road leading from the northwest side of Šušelj to the village should also be attributed to the Roman period on the basis of its description. ${ }^{11}$ A Late Classical structure was discovered next to the church of Our Lady of the Well (Gospe Čatrnjske), which dominates the entrance to the village from the southwest. ${ }^{12}$ It is possible that this is a Roman farm building that was modified and used in the early Christian period. Finds of several fragments of early-mediaeval sculpture indicate that there was a pre-Romanesque church nearby. ${ }^{13}$ An earring and an iron spur originate from the graves that were discovered next to the parish church, so, considering the findings of the sculpture and tombstones, it can be assumed that this is a graveyard that developed next to the church and lasted until the Late Middle Ages. ${ }^{14}$ The importance of Lukar in the time of the early-mediaeval Croatian Principality is especially testified to by the gold coins of Byzantine emperor Theophilus,






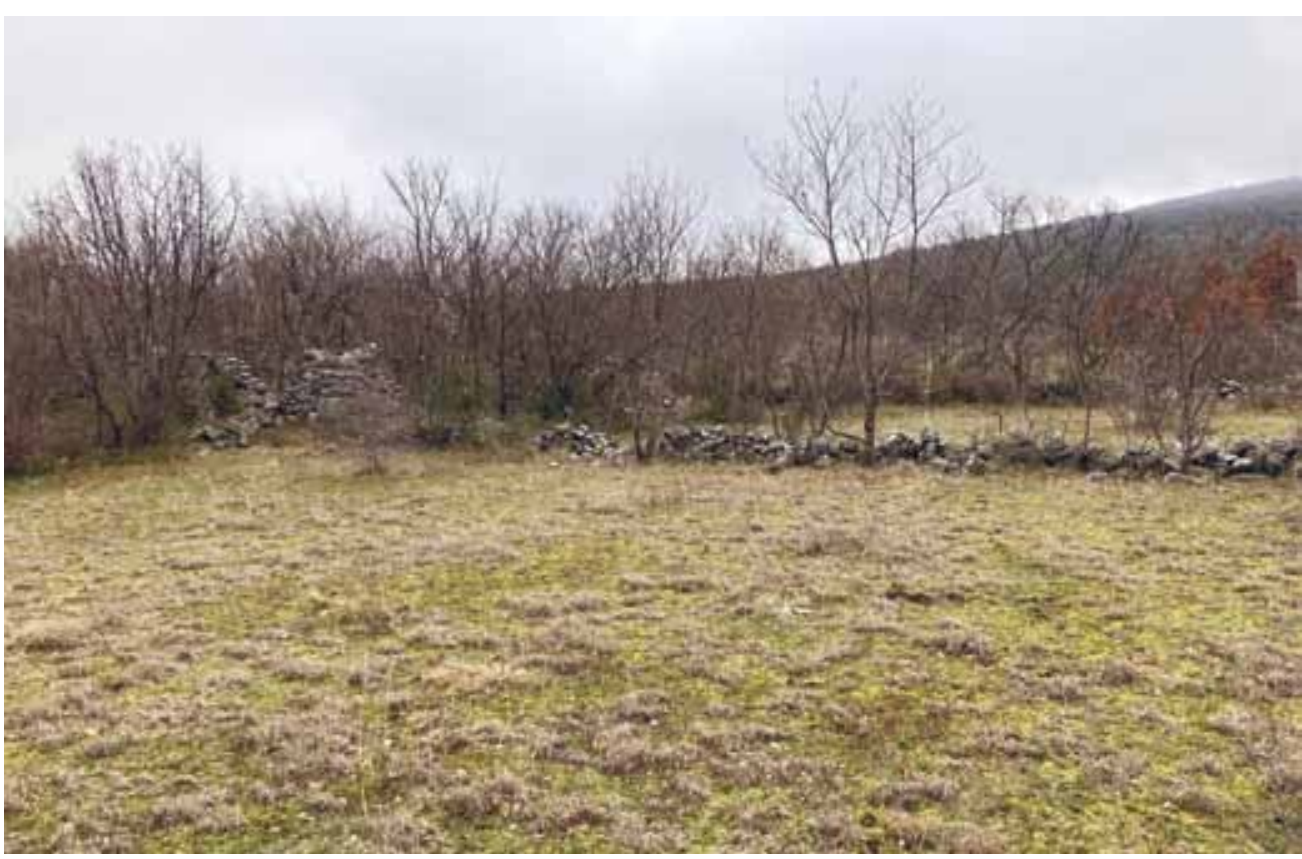

SLIKA 1. Položaj Kosaluša s ostacima Sarića tora (snimio T. Šeparović).

FIGURE 1. Position of Kosaluša with the remains of Sarić's holding pen (photo by T. Šeparović).

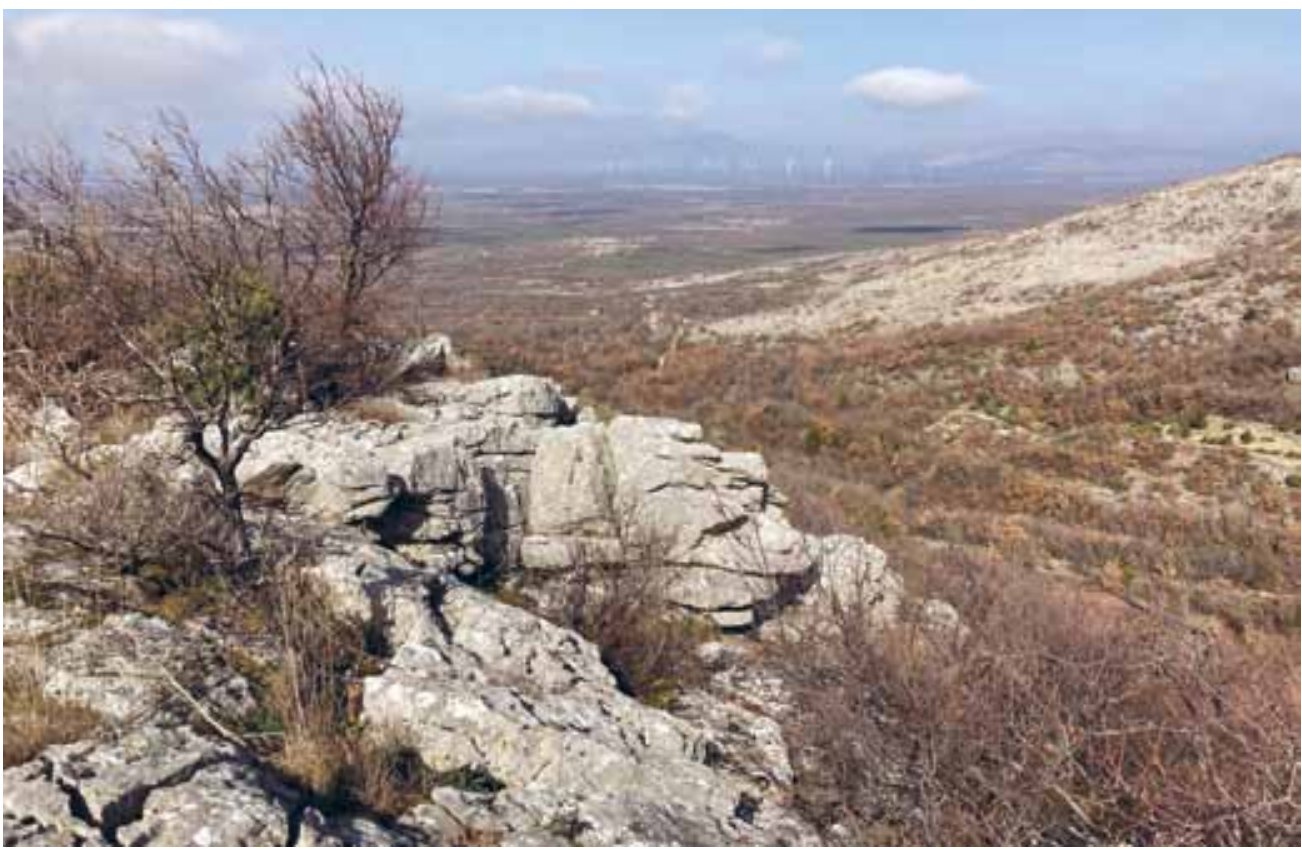

SLIKA 2. Pogled s Gradine kod Čulina na obronke Male Promine i prema Kosaluši (snimio T. Šeparović)

FIGURE 2. View from Gradina near Čuline over the slopes of Mala Promina and towards Kosaluša (photo by T. Šeparović).
Čine širi prostor koji se obrađivao i gdje su od davnina bili torovi za čuvanje stoke. ${ }^{18}$ Stoga, i preciznije je određivanje mjesta nalaza jako teško. S obzirom na prezime nalaznika, pretpostavljam da je novac pronađen na zemlji kod Sarića tora premda se to sa sigurnošću ne može tvrditi (sl. 1-2). one of which was found on Gradina, while the other is from an unknown location. ${ }^{15}$ While visiting Lukar with my colleague Maja Petrinec in January and February 2021, we were accompanied by Mr. Josip Čulina, a local, who gave us more interesting information about this area. ${ }^{16}$ We were especially interested in the position of Kosaluša, as it was there that Luka Sarić of Lukar found Theodoric's gold coin when he ploughed the field in 1910.17 The
18 Lokalno stanovništvo koristi i pluralni oblik Kosaluše, što potvrđuje da je riječ o više zemljišta obuhvaćenih tim imenom.
15 Marun 1998, 206; Šeparović 2020, 19. Marun uses the plural form for the finding site: in Gradine. It is possible that he meant the area of Mastirine and Gradina near the hamlet of Čuline.

16 My warmest words of gratitude to Mr Josip Čulina for his kindness and help. My thanks also go to Mrs Ivana Čulina, legal counsel at the Museum of Croatian Archaeological Monuments.

17 Marun mentions the finding site as Košaluša, but we use the name that is common today (Marun 1998, 198). 


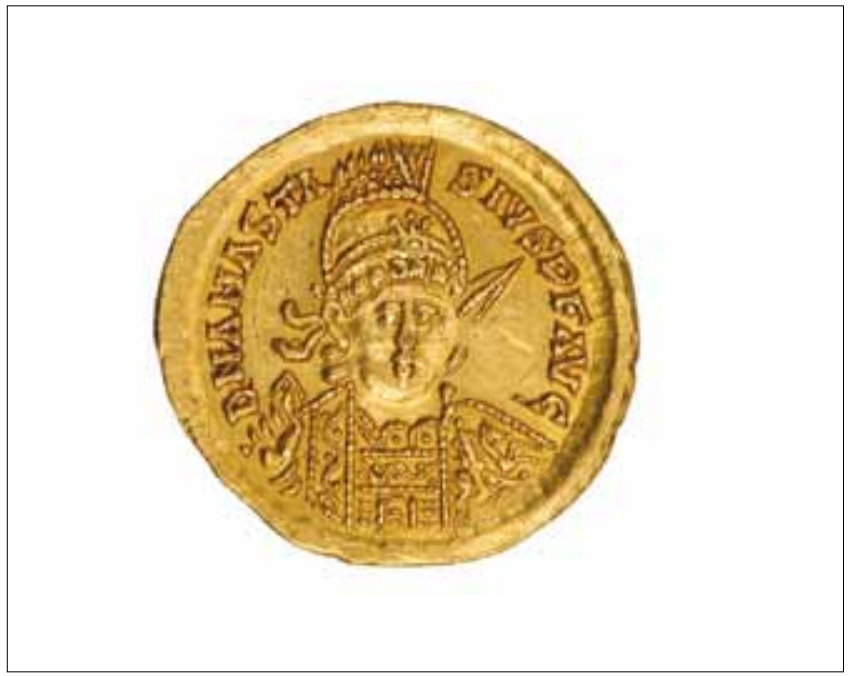

SLIKA 3A. Slika aversa (snimio Z. Alajbeg). FIGURE 3A. Obverse (photo by Z. Alajbeg).

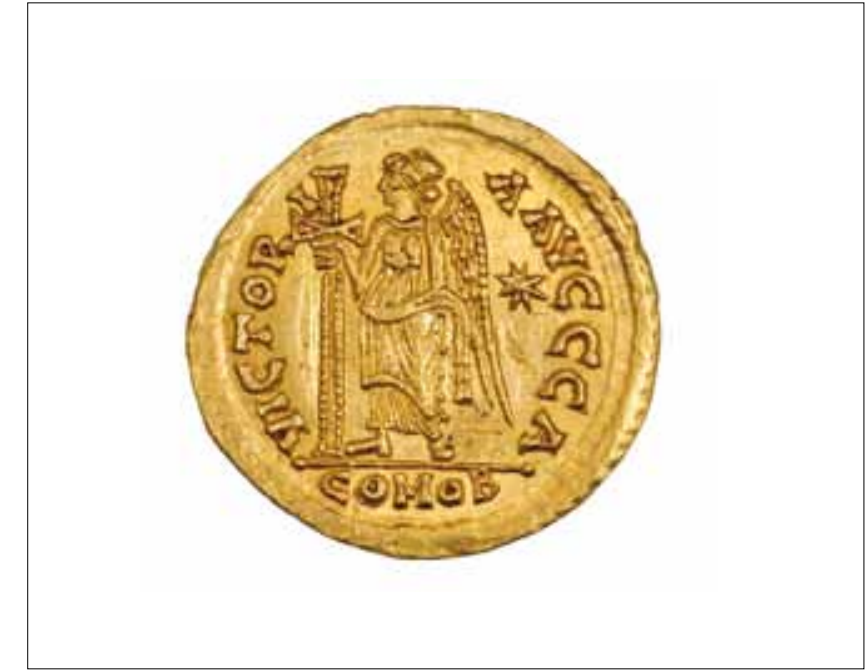

SLIKA зB. Slika reversa (snimio Z. Alajbeg). FIGURE 3B. Reverse (photo by Z. Alajbeg).

Opis novca:

Solid; Teodorik u ime Anastazija; kovnica: Rim nakon 497. godine. Zlato; dimenzije: $20 \mathrm{~mm}$; težina $4.44 \mathrm{~g}$; položaj kalupa 6.

Avers: DN ANASTASIVS PF AVG; poprsje cara koji nosi kacigu s perjanicom, trolisnim ukrasom i dijademom. Obučen je u paludamentum i oklop. Desnom rukom drži koplje iza glave. Na lijevom je ramenu štit s prikazom konjanika koji kopljem probada neprijatelja.

Revers: VICTORIA AVCCCA; Viktorija na lijevo s dugim križem, desno osmokraka zvijezda, u egzergu COMOB.

Nalazište: Lukar - Kosaluša (Košaluša)

Muzej hrvatskih arheoloških spomenika; inventarni broj 1255.

MIB 1, br. 9, Demo 1994, br. 5-7; Baldi 2014, br. 47.1;

Šeparović 2020a, 20, br. 28. location of Kosaluša lies north of the village, at the foot of Mala Promina. These are several plots of land which, together with a site called Banica, form a wider area that has been cultivated, and where holding pens for cattle have been located for a long time. ${ }^{18}$ Therefore, it is very difficult to determine the location of the find more precisely. Considering the surname of the finder, I assume that the coin was found on the ground near the Sarić pen, although this cannot be claimed with certainty (Fig. 1-2).

Description of the coin:

Solidus; Theodoric in the name of Anastasius; mint: Rome after 497 AD.

Gold; dimensions: 20 mm; weight $4.44 \mathrm{gr}$; mould position 6.

Obverse: DN ANASTASIVS PF AVG; a bust of the emperor wearing a helmet with a feather, a three-leafed ornament and a diadem. He is dressed in a cuirass and paludamentum, in his right hand holding a barbed spear behind his head. On his left shoulder is a shield depicting a horseman stabbing an enemy with a spear. Reverse: VICTORIA AVCCCA; Victoria on the left with a long cross, on the right an eight-pointed star, in exergue COMOB.

Finding place: Lukar-Kosaluša (Košaluša)

Museum of Croatian Archaeological Monuments; inventory number 1255 .

MIB 1, no. 9; Demo 1994, nos 5-7; Baldi 2014, no. 47.1;

Šeparović 2020a, 20, no. 28.

18 The locals also use the plural form, Kosaluše, which confirms that the name refers to several plots. 
Zlatni Teodorikov solid, kovan u ime bizantskog cara Anastazija, emitiran je iz kovnice grada Rima koji Istočni Goti zauzimaju nakon 490. godine. Od tada se tu kuju zlatnici i srebrnjaci u ime bizantskih vladara kao znak poštovanja cara u Konstantinopolu te priznanja njegove vrhovne vlasti na teritoriju nekadašnjega Rimskog Carstva. ${ }^{19}$ Od sličnih primjeraka kovanih u Konstantinopolu razlikuje se stilski, odnosno još kvalitetnijom izradom prikaza na aversu i reversu. ${ }^{20}$ Razlike su i u legendi - na aversu konstantinopolskog solida kratica je PP, a na rimskom PF. ${ }^{21}$ Najuočljivija je razlika u egzergu reversa gdje rimski solid ima natpis COMOB, a konstantinopolski CONOB. ${ }^{22}$ Karakteristika je rimskih solida oznaka A na kraju legende reversa, što označava prvu i ujedno jedinu oficinu za zlatne novce. ${ }^{23}$ Često imaju i slova u ligaturi u polju reversa lijevo, što nije slučaj kod lukarskog primjerka. ${ }^{24}$ Po svom stilu, ovakvi solidi slijede ranije Zenonove primjerke koje karakterizira poprsje $3 / 4 \mathrm{u}$ desno, temeljeno na tradiciji rimskog novčarstva. Ovaj je tip novca kovan za cijele Teodorikove, Atalarikove, a moguće i kratke Teodahadove vladavine. ${ }^{25}$ Identični primjerci Teodorikova solida registrirani su u muzejskim zbirkama, ali, na žalost, bez točnih podataka o mjestu nalaza. ${ }^{26}$ Inačice toga novca nalazimo u skupnim nalazima na otocima Kaprije ${ }^{27}$ i Ist (pod Turtulov). ${ }^{28}$ Po opisima znamo da pripadaju tipu koji, za razliku od primjerka iz Lukara, imaju oznaku u polju reversa. Zlatni su Teodorikovi solidi registrirani na još dva nalazišta u Hrvatskoj. Jedan, također kovan u Anastazijevo ime, porijeklom iz Dubrovnika, nekad se nalazio u zbirci Arheološkog muzeja u Zadru, ali, na žalost, nije preživio ratni vihor. ${ }^{29}$ Drugi je primjerak iz Baćina kod Hrvatske Kostajnice, kovan u ime Justina $1 .{ }^{30}$ Češće su zlatne Teodorikove tremise kovane za Anastazija. Najsjeverniji je hrvatski nalaz u Sisku. ${ }^{31} \mathrm{U}$ Lici su zabilježena četiri primjerka, i to u mjestima Kupirovo, ${ }^{32}$ Križpolje, $^{33}$ Donji Vaganac ${ }^{34}$ te na području Gospića. ${ }^{35}$ Iz Bosne i Hercegovine poznati su primjerci iz područja Tomislavgrada ${ }^{36}$ i Banjalučke regije, ${ }^{37}$ zatim grobni nalaz iz mjesta Donje Vrtoče - Morača kod Drvara ${ }^{38}$ te iz Brezika Laminci kod
The gold solidus of Theodoric, minted in the name of Byzantine emperor Anastasius, was issued by the mint of the city of Rome, which was occupied by the Ostrogoths after 490 . Since then, gold and silver coins had been minted there in the name of Byzantine rulers as a sign of respect for the emperor in Constantinople and recognition of his supreme authority in the territory of the former Roman Empire. ${ }^{19}$ This solidus differs in terms of style from similar specimens minted in Constantinople, displaying an even better minting quality on the obverse and reverse. ${ }^{20}$ Differences are also evident in the legend; the obverse of the Constantinople solidus shows the abbreviation PP, while the Roman shows $P F^{21}$ The most noticeable difference is in the exergue of the reverse; the Roman solidus has the inscription $C O M O B$, and the Constantinople has CONOB. ${ }^{22}$ The distinctive feature of Roman solidi is the mark $A$ at the end of the legend on the reverse, which denotes the first and, at the same time, only officina for gold coins. ${ }^{23}$ They often also have letters in the ligature in the field on the reverse on the left, which is not the case with the specimen from Lukar. ${ }^{24}$ In their style, these solidi follow earlier specimens of Zeno, which are characterized by a bust $3 / 4$ to the right, based on the tradition of Roman coins. This type of coin was minted throughout the reigns of Theodoric and Athalaric, and possibly during the brief rule of Theodahad. ${ }^{25}$ Identical specimens to Theodoric's solidus have been registered in museum collections - but, unfortunately, without any exact data on the site of the find. ${ }^{26}$ Variants of these coins have been discovered in hoards on the islands of Kaprije ${ }^{27}$ and Ist (below Turtulov). ${ }^{28}$ We know from their descriptions that they belong to a type which, unlike the specimen from Lukar, has a mark in the reverse field. Theodoric's gold solidi have been recorded at two other sites in Croatia. One originally from Dubrovnik, also minted in the name of Anastasius, was once in the collection of the Archaeological Museum in Zadar, but, unfortunately, did not survive the turmoil of war. ${ }^{29}$ The second specimen is from the village of Baćin, near Hrvatska
19 Grierson, Blackburn 1986, 432-434. Kuju se i brončani novci.

20 Grierson, Blackburn 1986, 34.

21 MIB 1, 80.

22 Marun čini pogrešku pri opisu novca navodeći CONOB vjerojatno zbog činjenice da je isti dan ranije za Muzej otkupio dva Zenonova zlatnika s takvim natpisom (Marun 1998, 197, 198).

23 Vidi komentar kustosa u: https://www.britishmuseum.org/collection/ object/C_1864-1128-217.

24 MIB 1, br. 7.

25 Za primjerke Atalarika i Teodahada, vidi: MIB 1, br. 28; Demo 1994, 91, 98.

26 Demo 1981, 475, br. 6; Demo 1994, 76, 77, br. 5-7

27 Bulić 1901, 70; Demo 1994, 76, br. 4

28 Bulić 1900, 192; Demo 1994, 76, br. 3.

29 Demo 1994, 86, br. 82; Demo 1996, 176, br. 8.

30 Demo 1994, 86, br. 90.

31 Pronađen u Kupi (Demo 1994, 83, br. 66; Mirnik, Šemrov 1998, 143, br. 2).

32 Mirnik, Šemrov 1998, 204, br. 813

33 Mirnik, Šemrov 1998, 203, br. 803

34 Mirnik, Šemrov 1998, 203, br. 798.

35 Mirnik, Šemrov 1998, 204, br. 811.

$36 \quad$ Patsch 1900, 565, br. 37.

37 Demo 1994, 83, br. 65. Demo pretpostavlja da potječe iz okolice Prijedora (Demo 1996, 173).

38 Patsch 1900, 565, br. 36; Demo 1994, 78, br. 13
NOB, probably due to the fact that he bought two Zeno gold coins with such an inscription for the Museum the same day (Marun 1998, 197, 198).

23 See curator's comment on https://www.britishmuseum.org/collection/ object/C_1864-1128-217

24 MIB 1, No.7.

25 For specimens of Athalaric and Theodahad, see MIB 1, No. 28; Demo 1994, 91,98

26 Demo 1981, 475, No. 6; Demo 1994, 76, 77, Nos 5-7

27 Bulić 1901, 70; Demo 1994, 76, No. 4

28 Bulić 1900, 192; Demo 1994, 76, No. 3

29 Demo 1994, 86, No. 82; Demo 1996, 176, No. 8. 
Bosanske Gradiške. ${ }^{39}$ Najbrojniji nalazi zlatnih Teodorikovih tremisa u ime Anastazija ipak su iz južne Hrvatske, a zabilježeni su na sljedećim nalazištima: Medviđa, ${ }^{40}$ okolica Benkovca, ${ }^{41}$ Solin, ${ }^{42}$ Danilo, ${ }^{43}$ Grahovo kod Dubravica, ${ }^{44} \mathrm{Nin}, 45$ Škabrnje ${ }^{46}$ te čak pet primjeraka u skupnom nalazu Klapavice kod Klisa. ${ }^{47}$ Iz tog su nalaza i dvije Teodorikove srebrne $1 / 4$ silikve kovane u ime Anastazija ${ }^{48}$ te jedna Teodorikova tremisa kovana u ime Zenona. ${ }^{49}$ Imitacija je takve tremise poznata iz Perušića kod Benkovca. ${ }^{50}$ Zanimljivo je ovdje ukazati i na nalaze istovremenih carskih Anastazijevih zlatnika jer su i oni bili u redovnom optjecaju na ovom prostoru, zajedno s istočnogotskim novcem. Na drniškom području to je solid konstantinopolske kovnice, pronađen u mjestu Umljanović koji se nalazi na pravcu rimske ceste Salona, Andetrij, Burnum. ${ }^{51}$ Anastazijeva je tremisa pronađena u Kadinoj Glavici, ${ }^{52}$ dok se u Tepljuhu na položaju Klanac s istočne strane Promine spominje Anastazijev zlatnik a da se ne navodi nominala. ${ }^{53} \mathrm{Na}$ neutvrđenome nalazištu kninskog područja zabilježen je jedan Anastazijev solid, ${ }^{54}$ dok je iz mjesta Pađene Anastazijeva tremisa. ${ }^{55}$

Sudeći prema arheološkim nalazima, Istočnih Gota u Dalmaciji nije bilo puno, no bili su dobro organizirani. ${ }^{56} \mathrm{O}$ njihovoj materijalnoj ostavštini dosta je pisano u stručnoj i znanstvenoj literaturi. ${ }^{57}$ Što se numizmatičkih nalaza tiče, gledajući područje rimske Dalmacije, koju su zaposjeli 493. godine, tu je zabilježeno 60 primjeraka istočnogotskog novca s koliko-toliko poznatim mjestom nalaza. ${ }^{58}$ Nalaza je najviše na obali i u zaobalju, dok ih je duboko u unutrašnjosti znatno manje. Recimo da ih je u Bosni i Hercegovini zabilježeno samo devet primjeraka..$^{59}$ Može se pretpostaviti da ga je na tom području bilo više jer je unutrašnjost provincije
Kostajnica, minted in the name of Justin 1. ${ }^{30}$ Theodoric's gold tremisses were more often minted for Anastasius. The northernmost find in Croatia was discovered in Sisak. ${ }^{31}$ Four specimens have been recorded in Lika: in the settlements of Kupirovo, ${ }^{32}$ Križpolje ${ }^{33}$ and Donji Vaganac, ${ }^{34}$ and in the area of Gospić. ${ }^{35}$ From Bosnia and Herzegovina, we know about specimens from the area of Tomislavgrad ${ }^{36}$ and the Banja Luka region, ${ }^{37}$ as well as a grave find from the settlement at Donje Vrtoče-Morača, near Drvar, ${ }^{38}$ and from Laminci Brezici, near Bosanska Gradiška. ${ }^{39}$ The most numerous finds of Theodoric's gold tremisses in the name of Anastasius originate from southern Croatia. They were recorded at the following sites: Medviđa, ${ }^{40}$ surroundings of Benkovac, ${ }^{41}$ Solin, ${ }^{42}$ Danilo, ${ }^{43}$ Grahovo near Dubravica, ${ }^{44}$ Nin, ${ }^{45}$ Škabrnja, ${ }^{46}$ and as many as five specimens in the hoard of Klapavica, near Klis.47 Also belonging to this find are two Theodoric silver quartersiliquae minted in the name of Anastasius, ${ }^{48}$ and one Theodoric tremissis minted in the name of Zeno. ${ }^{49} \mathrm{An}$ imitation of such a tremissis is known from Perušić, near Benkovac. ${ }^{50}$ Also worth mentioning here are findings of contemporaneous imperial gold coins of Anastasius, because they - together with Ostrogothic coins - were also in regular circulation in this area. In the Drniš area, it is a solidus of the Constantinople mint that was found in the village of Umljanović, which is located along the Roman road Salona- Andetrium-Burnum. ${ }^{51}$ Anastasius's tremissis was found in Kadina Glavica, ${ }^{52}$ while in Tepljuh, at the site of Klanac on the east side of Promina, an Anastasius gold coin is mentioned with out statement of the denomination. ${ }^{53}$ One solidus of Anastasius was found at an unidentified site in the area of Knin, ${ }^{44}$ and one tremissis of Anastasius in the village of Pađene. ${ }^{55}$

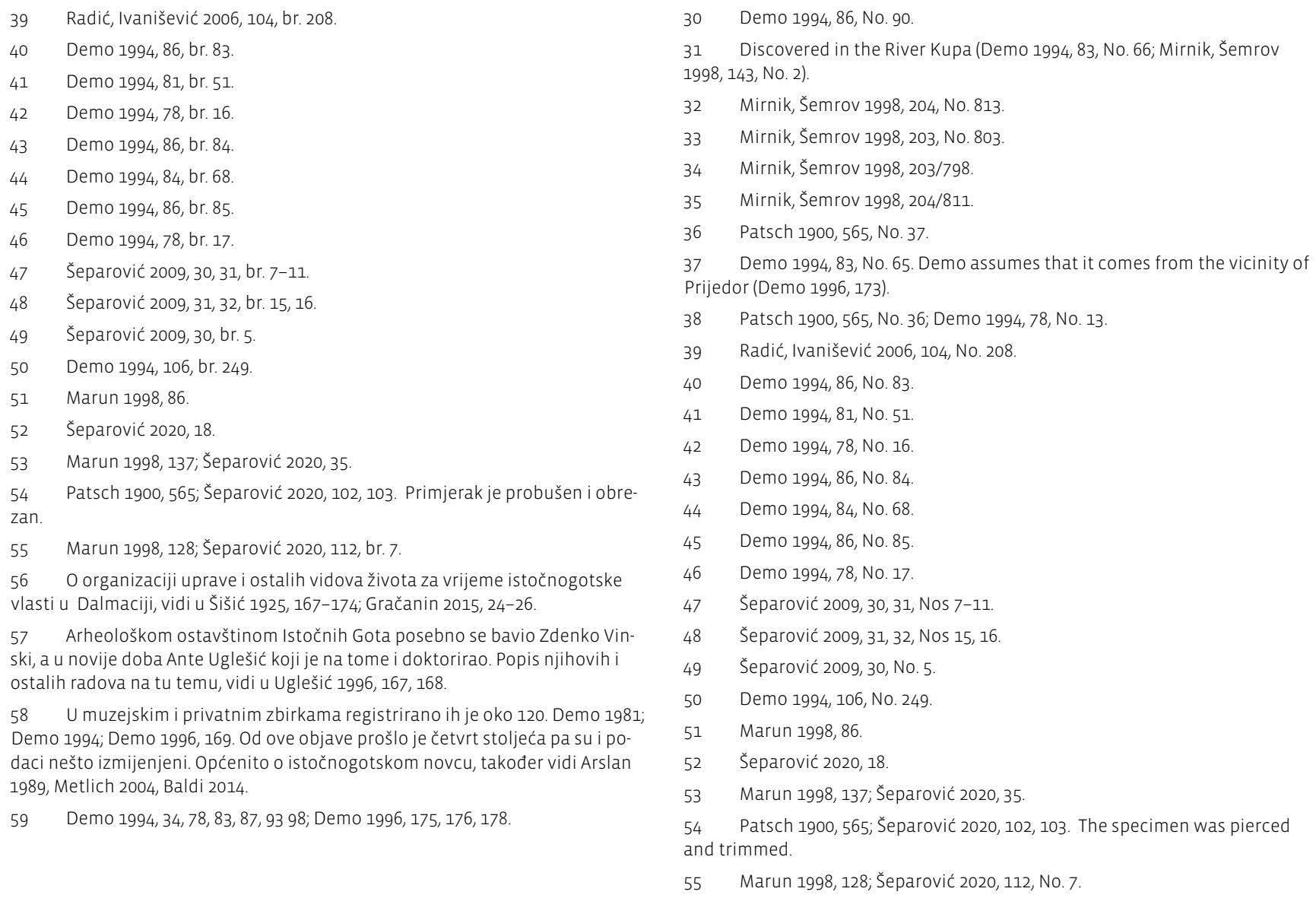






SLIKA 4. Pogled s bedema Gradine kod Čulina na gradinu Šušelj (snimio T. Šeparović).

FIGURE 4. View from the Gradina ramparts near Čuline over the Šušelj hill-fort (photo by T. Šeparović).

Dalmacije bila Istočnim Gotima posebno značajna zbog rudnog bogatstva. ${ }^{60}$ Razlog leži u tome što dobar dio bizantskog novca toga vremena nije bilo moguće pregledati pa je veliko pitanje u kojoj je mjeri taj novac točno atribuiran. Sasvim je izvjesno da dio novca, posebno zlatnika, pripada istočnogotskim kovnicama. Deset primjeraka srebrnog i brončanog istočnogotskoga novca pronađenog u Sisku ukazuje na značaj centra Panonije Savije koja je u to doba, zajedno s Dalmacijom, činila jednu upravnu cjelinu. ${ }^{61}$

S nalazišta južne Hrvatske potječe ukupno 44 primjerka istočnogotskog novca. Od toga ih je u sjevernoj Dalmaciji evidentirano 13, u srednjoj Dalmaciji 27, a u južnoj 4 (tablica 1). Uspoređujući njihov udio u južnoj Hrvatskoj, uočavamo znatno veći postotak Teodorikovih kovova emitiranih u ime Anastazija u odnosu na novac ostalih vladara. U srednjoj Dalmaciji je udio tih kovova samo nešto veći od udjela Atalarikova novca kovanog u ime Justinijana. Jasno je da su Istočni Goti koncentrirali glavninu svojih snaga oko Salone, što je vidljivo i po numizmatičkim nalazima. Pregledom nalaza postaje jasno da se dotok istočnogotskog novca prema sredini 6 . stoljeća postupno smanjuje. Takvo stanje
Judging by the archaeological findings, there were not many Ostrogoths in Dalmatia; they were, however, well organized. ${ }^{66}$ Much has been written about their material legacy in the expert and scientific literature. ${ }^{57}$ As for numismatic finds in the area of Roman Dalmatia, which they occupied in 493, sixty specimens of Ostrogothic coins are recorded with more or less known places of discovery. ${ }^{58}$ Most specimens were found on the coast and in the hinterland, while their numbers significantly decrease deeper into the interior of the country. Only nine of them have been discovered in Bosnia and Herzegovina. ${ }^{59}$ It can be assumed that there were more of them in this area, because the interior of the province of Dalmatia was particularly important to the Ostrogths, due to its mineral resources. ${ }^{60}$ The reason lies in the fact that a significant number of the Byzantine coins of that time could not be examined; hence the big question is to what extent the coins have been exactly attributed. It is quite certain that some of the coins, especially the gold coins, belong to Ostrogothic mints. Ten Ostrogothic silver and bronze coins found in Sisak indicate the importance of the centre of Pannonia Savia, which at that time formed one administrative unit together with Dalmatia. ${ }^{61}$

\footnotetext{
60 Šišić 1925, 169.

61 Mirnik, Šemrov 1998, 142.
}

56 On the organization of the administration and other aspects of life during the Ostrogoth rule in Dalmatia, see Šišić 1925, 167-174; Gračanin 2015, 2426.

57 Especially Zdenko Vinski, and more recently Ante Uglešić, who also received his doctorate on this topic, have dealt with the archaeological legacy of the Ostrogoths. For a list of their works and others' on this subject, see Uglešić $1996,167,168$

58 About 120 of them have been registered in museum and private collections. Demo 1981; Demo 1994; Demo 1996, 169. A quarter of a century has passed since this publication, so the data has changed somewhat. On Ostrogothic coinage in general, see also: Arslan 1989, Metlich 2004, Baldi 2014

59 Demo 1994, 34, 78, 83, 87, 93 98; Demo 1996, 175, 176, 178.

60 Šišić 1925, 169.

61 Mirnik, Šemrov 1998, 142. 
SLIKA 5. Pogled s Gradine kod Čulina na prijevoj preko Promine (snimio T. Šeparović).

FIGURE 5. View from Gradina near Čuline of the pass over Promina (photo by T. Šeparović).

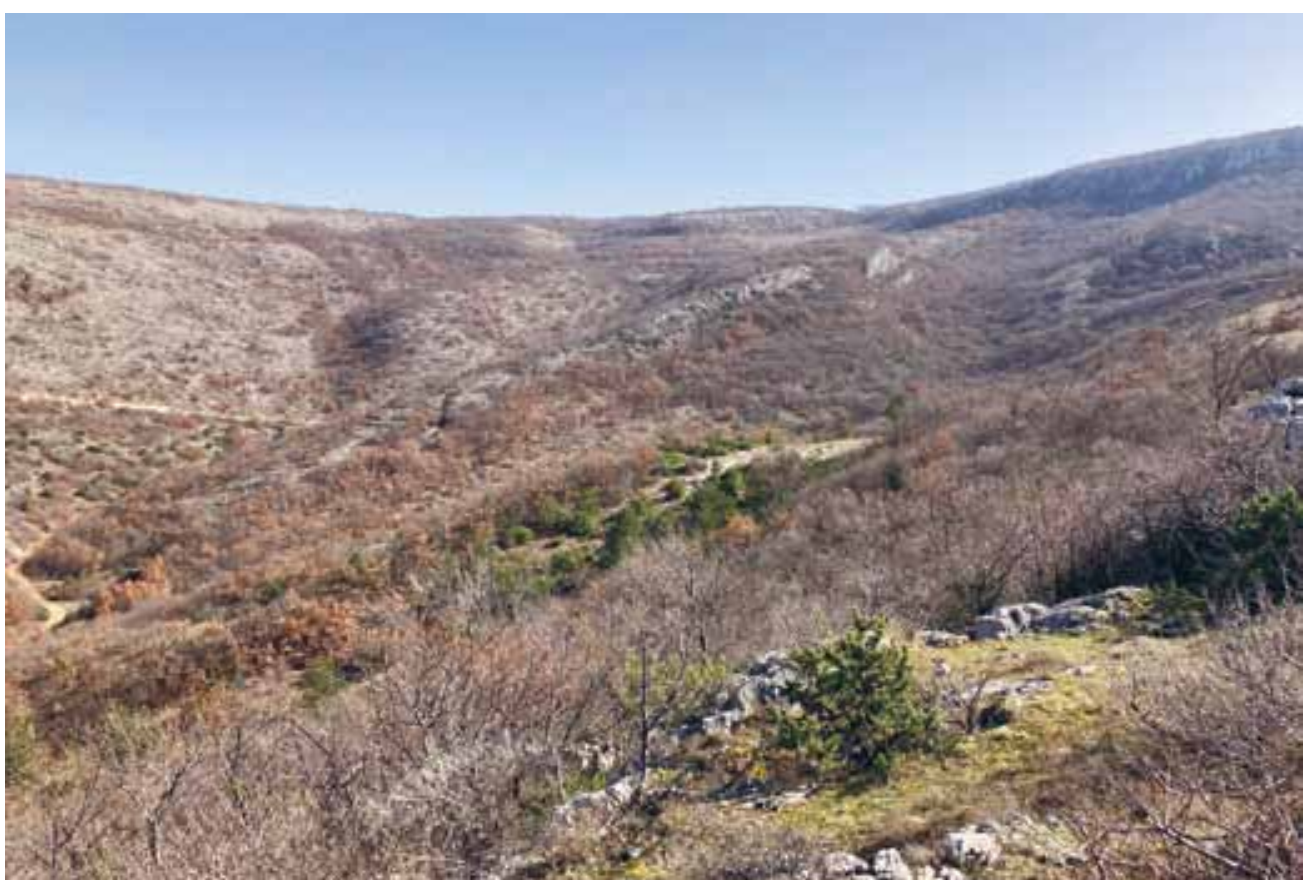

\begin{tabular}{|c|c|c|c|}
\hline $\begin{array}{c}\text { Vladar } \\
\text { / Ruler }\end{array}$ & $\begin{array}{c}\text { Sjeverna } \\
\text { Dalmacija } \\
\text { / Northern } \\
\text { Dalmatia }\end{array}$ & $\begin{array}{c}\text { Srednja } \\
\text { Dalmacija } \\
\text { / Central } \\
\text { Dalmatia }\end{array}$ & $\begin{array}{c}\text { Južna } \\
\text { Dalmacija } \\
\text { / Southern } \\
\text { Dalmatia }\end{array}$ \\
\hline $\begin{array}{c}\text { Teodorik } \\
\text { / Theodoric } \\
\text { (488-526) }\end{array}$ & 10 & 10 & 1 \\
\hline $\begin{array}{c}\text { Atalarik } \\
\text { Athalaric } \\
\text { (526-534) }\end{array}$ & 1 & 8 & 1 \\
\hline $\begin{array}{c}\text { Teodahad } \\
\text { / Theodahad } \\
\text { (534-536) }\end{array}$ & 1 & 4 & 1 \\
\hline $\begin{array}{c}\text { Vitigis } \\
\text { / Vitiges } \\
\text { (536-540) }\end{array}$ & 1 & 1 & 1 \\
\hline $\begin{array}{c}\text { Totila } \\
\text { / Totila } \\
\text { (541-552) }\end{array}$ & 1 & & \\
\hline
\end{tabular}

TABLICA 1. Broj primjeraka istočnogotskog novca po carevima u južnoj Hrvatskoj (izradio T. Šeparović).

TABLE 1. Number of specimens of Ostrogothic coins by emperors in southern Croatia (made by T. Šeparović).
A total of 44 specimens of Ostrogothic coinage originate from finding sites in southern Croatia, of which 13 were recorded in northern Dalmatia, 27 in central Dalmatia and 4 in southern Dalmatia (Table 1). Comparing their proportion in southern Croatia, we notice a significantly higher percentage of Theodoric's coins minted in the name of Anastasius than of the coins of other rulers. In central Dalmatia, the proportion of these coins is only slightly higher than the proportion of Athalaric's coins minted in the name of Justinian. It is clear that the Ostrogoths stationed the majority of their military forces around Salona, which is also evident from the numismatic findings. A review of the findings reveals that the inflow of Ostrogothic coins gradually decreased towards the mid- $6^{\text {th }}$ century. Such a situation can be explained by the political crisis in the second third of the $6^{\text {th }}$ century, when Emperor Justinian launched a decisive military action against the Ostrogoths to defend Byzantine interests. Valuable information about the war that broke out, especially around Salona, was given by the historian Procopius of Caesarea. ${ }^{62}$ After the fortune of war eventually turned, the Byzantine military leader Constantinianus was finally able to liberate Salona in 536 and successfully defend it in the years that followed, thereby bringing all Dalmatia permanently under Byzantine rule, while the Goths retreated towards Italy. ${ }^{63}$ With respect to the subject of this paper, particularly interesting are the events and developments happening at that time in the area west of the Promina mountain, especially in the middle course of the River Krka, where the most important settlement was Burnum. The find of Theodoric's gold solidus at Lukar should hence be linked to the situation in Burnum during the dominance of the Ostrogoths, bearing in mind that such gold coins could have been in circulation over a long 
može se objasniti političkom krizom u drugoj trećini 6. stoljeća, kada car Justinijan u obrani bizantskih interesa od Istočnih Gota pokreće odlučnu vojnu akciju. O ratu koji se razbuktao, posebno oko Salone, podatke donosi povjesničar Prokopije iz Cezareje. ${ }^{62}$ Nakon promjenjive ratne sreće, konačno 536 . godine Salonu oslobađa, a u sljedećim godinama i uspješno brani, bizantski vojskovođa Konstancijan. Time cijela Dalmacija trajno potpada pod bizantsku vlast, a Goti se povlače prema Italiji. ${ }^{63}$ Zbog teme rada, posebno je zanimljivo što se u to doba događa s prostorom zapadno od planine Promine, posebice srednjeg toka rijeke Krke, gdje je najvažnije naselje bilo Burnum. Nalaz zlatnog Teodorikova solida iz Lukara upravo treba povezati s prilikama u Burnumu tijekom istočnogotske vladavine, pri čemu treba imati na umu da su ovakvi zlatnici mogli biti dugo u opticaju, što potvrđuju skupni nalazi novca. ${ }^{64}$ Taj nekadašnji rimski vojni logor i municipij bio je Istočnim Gotima od velike važnosti i od početka njihove vladavine u Dalmaciji mjesto gdje su boravili gradski službenici, odnosno magistrati podložni gotskom komesu, ali i vojne jedinice. ${ }^{65} \mathrm{U}$ Burnum se privremeno sklonila gotska vojska i prije zadnjeg pokušaja da Salonu vrati pod svoju vlast. ${ }^{66}$ Tada se popravljaju stari rimski bedemi radi što sigurnijeg boravka vojnih postrojbi na tome mjestu. Poznato je da su Goti dobivali trećinu državnog zemljišta, kakvog je bilo i na širem području Promine sa zapadne i istočne strane. ${ }^{67}$ Sva je ta zemlja, pa tako i oranice i pašnjaci na prostoru Kosaluša, te između Šušelja i gradine kod zaseoka Čuline, u rimsko vrijeme bila dio burnumskog agera, a dijelom je kasnije pripala Gotima (sl. 4). ${ }^{68} \mathrm{Uz}$ izvore vode, zemlja je bila prijeko potrebna za proizvodnju hrane, uzgoj žitarica te ispašu sitnije stoke. ${ }^{69}$ Nakon zauzimanja Dalmacije, a posebno u doba rata s Bizantom, ključno je bilo osigurati upravna mjesta poput Burnuma, držeći vojne posade na strateškim punktovima u blizini, kao što je to bio slučaj s uporištima u zaleđu Salone. ${ }^{70} \mathrm{Za}$ osiguranje Burnuma s istočne strane značajna su bila strateška uporišta kod Lukara, Šušelj i gradina kod zaseoka Čuline jer se tuda, preko prijevoja na Promini iz pravca salonitanskog zaleđa, moglo izbiti na Krku u njegovu blizinu (sl. 5). To je područje bilo posebno osjetljivo zbog više pogodnih riječnih prijelaza. Za logističku potporu, odnosno opskrbu prijeko potrebnim namirnicama vojnih posada smještenih na tim položajima, važni su bili pašnjaci i oranice u blizini, poput onih na prostoru Kosaluše. Vojne posade, zadužene za osiguranje naselja i prometnica, bile su najčešće plaćene u zlatnom novcu te je i Teodorikov solid iz Lukara, bez sumnje, bio u toj funkciji. Koliko je dugo kolao prije negoli je dospio u zemlju, teško je reći, no, budući da je Burnum napušten oko 537. godine, pretpostavljam da je to gornja granica za dataciju njegova opticaja. period of time, which is confirmed by the hoard of coins. ${ }^{64}$ This former Roman legion camp and municipium was of great importance to the Ostrogoths. From the beginning of their rule in Dalmatia, it was a place where city officials or magistrates resided, subordinated to the comes Gothorum, and military units were stationed. ${ }^{65}$ The Gothic army temporarily took refuge in Burnum even before their last attempt to bring Salona back under their rule. ${ }^{66}$ It was during that time that the old Roman ramparts were repaired so that the military troops would be as safe as possible there. It is known that the Goths were receiving a third of public land, and such land was available in the wider area of Promina on its western and eastern side. ${ }^{67}$ All this land, including arable land and pastures in the area of Kosaluša, and between Šušelj and the hill-fort near the hamlet of Čuline, was part of the Burnum ager in Roman times, and part of it later fell to the Goths (Fig. 4). ${ }^{68}$ In addition to the important water sources there, the land was indispensable for food production and the cultivation of cereal crops, and as pastureland for small cattle. ${ }^{69}$ After the conquest of Dalmatia, and especially during the war with Byzantium, it was crucial to secure administrative places like Burnum and to keep military troops at strategic locations nearby, as was the case with strongholds in the hinterland of Salona. ${ }^{70}$ In order to keep Burnum secure from the east, the strategic strongholds at Lukar, Šušelj and the hill-fort near the hamlet of Čuline were rather important, because there was a passage which led across the pass on Promina from the direction of Salona's hinterland right to the River Krka near Burnum (Fig. 5). This area was particularly sensitive due to several convenient crossings over the river. For logistical support, i.e. the supply of much-needed food for the military troops that were stationed at these strongholds, pastures and arable land in close proximity, such as those in the area of Kosaluša, were vital. Troops in charge of securing the settlements and roads were most often paid in gold coins, and Theodoric's solidus from Lukar was used without doubt for that purpose. It is difficult to say how long the coin circulated before it came into the country, but since Burnum was abandoned around 537 , I assume that this would be the upper limit when dating its circulation



64 For example, the hoard from Klapavica, near Klis, contains barbarous gold coins with the image of the Eastern Roman emperor Leo, and also Athalaric's quarter-siliquae minted for Justinian, which is a time span of over 60 years.

65 Suić 1981,320

66 Goldstein 1992, 23; Gračanin 2015, 27

67 Šišić 1925, 170; Suić 1981, 320.

68 The Ostrogoths take over the old Roman demarcations. On the legionary territory of Burnum, see Zaninović 1985

69 Šišić 1925, 169; Goldstein 1995, 61, 62

70 On strategic strongholds in the hinterland of Salona, see Katić 2018. 


\section{BIBLIOGRAFIJA BIBLIOGRAPHY}

Arslan 1989 - E. Arslan, La monetazione dei Goti, Corso di cultura sull'Arte ravennate e bizantina 36, Ravenna, 14-22 april 1989, Edizioni del Girasole, 1989, 17-72.

Baldi 2014 - E. Baldi, Ostrogothic Coins in the The British Museum, The British Museum, 2014

Bulić 1900 - F. Bulić, Ritrovamenti di monete antiche sull'isola Isto presso Zara, Bulletino di archeologia e storia dalmata 23, 1900, 192.

Bulić 1901 - F. Bulić, Ritrovamenti di monete antiche sull'Isola di Kaprije di Sebenico, Bulletino di archeologia e storia dalmata 24, 1901, 70.

Buttler 1932 - W. Buttler, Die Burgwälle in Norddalmatien, Bericht Römisch Germanische Kommission 21, 1932, 183-198.

Demo 1981 - Ž. Demo, Novac germanskih vladara druge pol. 5. do u drugu pol 6. st. u numizmatičkoj zbirci Arheološkog muzeja u Zagrebu, Arheološki vestnik 32, 1981, 454-481.

Demo 1994 - Ž. Demo, Ostrogothic Coins from Collections in Croatia, Slovenia and Bosnia and Herzegovina, Situla 32, Narodni muzej Slovenije, 1994.

Demo 1996 - Ž. Demo, Istočnogotski novci Dalmacije, in Tafra, R. (ed.), Hrvati i Goti, Biblioteka Iberia, 1996, 169-179.

Goldstein 1992 - I. Goldstein, Bizant na Jadranu (od Justinijana I. do Bazilija I.), Latina et Graeca, Zavod za hrvatsku povijest Filozofskog fakulteta, 1992.

Goldstein 1995 - I. Goldstein, Hrvatski rani srednji vijek, Novi Liber, 1995.

Gračanin 2015 - H. Gračanin, Kraj antike na hrvatskim prostorima, in Nikolić Jakus, Z. (ed.), Nova zraka u europskom svjetlu, hrvatske zemlje u ranome srednjem vijeku (oko 550 - oko 1150), Matica hrvatska, 2015, 3-36.

Grierson, Blackburn 1986 - P. Grierson, M. Blackburn, Medieval European Coin age 1 , The Early Middle Ages ( $5^{\text {th }}-10^{\text {th }}$ centuries), Cambridge University Press, 1986.

Jurić 2018 - A. Jurić, Promina, Kulturno-povijesna baština, 2018.

Katić 2018 - M. Katić, Castella qui sunt super civitatem Salonitanam, Vjesnik za arheologiju i historiju dalmatinsku 111, 2018, 245-279.

Marun 1998 - L. Marun, Starinarski dnevnici, Muzej hrvatskih arheoloških spomenika, 1998.
Metlich 2004 - M. A. Metlich, The Coinage of Ostrogothic Italy, Spink, 2004.

MIB 1 - W. Hahn, Moneta Imperii Byzantini 1, Österreichische Akademie der Wissenschaften, 1973

Mirnik, Šemrov 1998 - I. Mirnik, A. Šemrov, Byzantine Coins in the Zagreb Archaeological Museum Numismatic Collection; Anastasius I (A.D. 497-518) - Anastasius II (A.D. 713-715), Vjesnik Arheološkog muzeja u Zagrebu 30-31, 1997$1998,129-258$

Patsch 1900 - K. Patsch, Nahogjaji novca, Glasnik Zemaljskog muzeja BiH 12, 1900, 543-573.

Perinec 2009 - M. Petrinec, Groblja na području ranosrednjovjekovne hrvatske države, Muzej hrvatskih arheoloških spomenika, 2009.

Radić, Ivanišević 2006 - V. Radić, V. Ivanišević, Vizantijski novac iz Narodnog muzeja u Beogradu / Byzantine Coins from the National Museum in Belgrade, National Museum in Belgrade, 2006

Suić 1981 - M. Suić, Zadar u starom vijeku, Filozofski fakultet Zadar, 1981.

Šeparović 2001 - T. Šeparović, Rimski okov sa Šušelja kod Drniša, Opuscula archaeologica 25, 2001, 65-75.

Šeparović 2009 - T. Šeparović, Skupni nalaz novca iz 5. i 6. stoljeća na lokalitetu Klapavice - Crkvina kod Klisa, Starohrvatska prosvjeta 36, 2009, 27-34.

Šeparović 2020 - T. Šeparović, Numizmatička topografija drniškog, kninskog $i$ šibenskog područja / Numismatic topography of the Drniš, Knin and šibenik areas, Muzej hrvatskih arheoloških spomenika, 2020

Šeparović 2020a - T. Šeparović, Numizmatička zbirka Muzeja hrvatskih arheoloških spomenika, katalog izložbe, Muzej hrvatskih arheoloških spomenika, 2020.

Šišić 1925 - F. Šišić, Povijest Hrvata u vrijeme narodnih vladara, Nakladni zavod Matice hrvatske, 1925

Uglešić 1996 - A. Uglešić, Nakit Istočnih Gota na području rimske provincije Dalmacije, in Tafra, R. (ed.), Hrvati i Goti, Biblioteka Iberia, 1996, 135-168.

Zaninović 1985 - M. Zaninović, Prata legionis u Kosovom polju kraj Knina s osvrtom na teritorij Tilurija, Opuscula archaeologica 10, 1985, 63-79. 